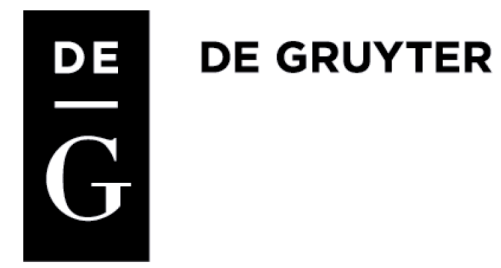

Robert Klementowski

(Institute of National Remembrance/University of Wrocław, Wrocław)

\title{
FINANCIAL CRIME IN THE OPERATIONAL WORK OF THE STATE SECURITY SERVICE UNTIL 1956 - LOWER SILESIAN PERSPECTIVE
}

Nationalization and the introduction of state-controlled economy led to the emergence of abnormal social phenomena, including system-specific crimes. Economic transformations were the foundation of the systemic revolution carried out in the first decade after the Second World War, therefore they were the subject of interest for the Ministry of Public Security. That is why financial crimes were treated just like political crimes, which was also justified by legal provisions, as no specific definition of this type of crime existed. This allowed the authorities (secret police, prosecutor's office, courts, media) to interpret the events according to their will and current political needs, and, as a result, to administer various overt or covert repressions (death penalty, imprisonment, forced cooperation with the secret police).

Keywords: financial crime, security services, Lower Silesia.

doi:10.1515/sho-2016-0008

\section{INTRODUCTION}

The problem of financial crime in the first years following the end of the Second World War was not a particularly interesting subject for historians. To some extent this is understandable, as political issues were of prime concern, including the creation of the Polish Workers Party/Polish United Worker's Party administration or the elimination of both real and sham opposition. The longer the research on this subject is conducted, the clearer it becomes that the bedrocks of the new system were not actually its repressive nature or single-party rule, but the permanent transformation of the economic system. The means to achieve this end in the case of Poland was an attempt by the state - a failed one, frankly speaking - to 
take control over the whole economy by eliminating private property and introducing state-controlled economy. ${ }^{1}$

Within a few years, this led to the emergence of the so-called second economic circle (commonly known as black market), and the development of permissive attitudes towards illegal activities aiming to provide individual social security. After the atrocities of the war, people willingly engaged in reconstructing not only the state, as propaganda claimed, but primarily their financial life. In other words - they were trying to make money. In this economic game of a kind, along with the consolidation of the communist power (PPR/PZPR) the state became the competitor, as, also for political reasons, it was increasingly treated as alien and hostile. In this context, the problem of individual actions which can be considered financial crimes seems interesting.

The evidence that the problem existed and was by no means marginal can be found in the archive materials of the former Ministry of Public Security, particularly with regards to the first decade of socialist Poland and the Polish People's Republic. This is the institution which at that time "delivered" a large number of people accused of crime to the war machine made up by prosecutors and courts. It is commonly believed that financial crime was the concern of the Militia, while the Security Service (SB) focused primarily on political cases, but actually, this clear division of tasks, appeared in official records as late as 1955, and in practice, in the late 1956, with the dissolution of the Security Office (UB). Before, the decision on constituted a "political case" was made by the communist party, by the security authorities and sometimes even by the rank and file of the department. ${ }^{2}$

Considering the year 1956 as the turning point is therefore absolutely justified here. Apart from organizational matters crucial for the history of the security service, only after this date one can actually talk about a broader discussion on the category of "financial crime". Finally, in terms of symbols, this date has to be treated as a closure of a certain stage in the post-WWII Polish history - the time when the majority of systemic changes had been introduced in the political (eliminating opposition, adoption of the new constitution), economic (nationalization of the economy, ex-

\footnotetext{
${ }^{1}$ Some land remained private property.

${ }^{2}$ In fact, in the early stages of investigations they were the ones who accused people and defined their behaviors, which then led to operational inquiries. Even if after a while, an officer's superiors decided that the operational inquiry is pointless, traces of the person (the subject of investigation) remained in the archives of the Security forever.
} 
cluding agriculture, which however was still subject to collectivization), and social and cultural aspects (control over the individual, social realism in literature and art, repression of churches and religions).

First of all, I will describe the difficulties in defining the problem. After that, I shall investigate what was considered financial crime in the context of the legislation in force at the time. The next part of the article is devoted to the institution for which, at least partially, this law was created, that is the Ministry of Public Security. I will indicate the extent to which the security service occupied itself with economic issues, and we will look at its structures and the tasks of its officers. I will try to explain why the security was interested in this category of crimes and how the knowledge acquired in investigations was used. I will finally present the attempts of explaining the term "financial crime" during Stalinist period, undertaken ex post, in the second half of the 1950s.

The problem of financial crime was the subject of articles concerning mainly the period after 1956 [Madej K. 2010]. The foundation of the present article includes literature on the concept of "financial crime", official materials (Journal of Laws) and archive materials of the former special services (reports, operational files), mostly from the area of Lower Silesia. The existing literature on the subject complements the source material and provides examples.

\section{FINANCIAL CRIME - AN ATTEMPT AT DEFINITION}

It is difficult to find one, universal definition of economy-related crime. This can be assumed to result from the multiple meanings of the terms: "crime", "economy" and "economic". They depend on political and social systems forming the context in which they are used. That is one reason why there are two, and according to some, even three primary definitions of "financial crime", created in different political and economic systems: "continental" (focused on the object), "American" (focused on the subject) and, recently, "European" (related to the creation of the EEC/ EU) [Wilk L. 2012: 12-16]. Apart from that, there are also Marxism-based theories which emphasized the criminal activity of exploiting the social classes of a low financial status by the so-called controlling classes [Wilk L. 2012: 12-16]. Considering the systemic economic changes in the coun- 
tries with state-controlled economy, some have even proposed a division into "traditional" and "new" financial crimes [Lernell L. 1959: 777-778]. Therefore, the statement of L. Wilk is not surprising. Referring to the literature, he writes that:

[...] the evolution of financial crime and its level of complexity both in terms of the subjects and the objects involved makes it impossible to construct one, general and universal definition of financial crime which could be considered timeless. Therefore, this is to some extent an agreed-on mental shortcut [Wilk L. 2012: 14].

Considering the historical context, one can venture a thesis that the economic system of the country determines the nature of economic crimes. The above-mentioned continental concept sees the essence of the crime in violating the collective goods of the economic life, in the lack of violence, and the anonymity of victims - individuals, branches and institutions of the economic life. The American concept focuses primarily on the subject committing the crime. For the purposes of our analysis, we shall stick to the continental concept and assume that financial crimes are illegal actions, attacking or jeopardizing the collective wellbeing in the economic aspect of life. Results may include undermining trust towards the economic system and its basic institutions, breaching the interests of the participants of the economic life, and finally, interfering with the government's financial institutions.

\section{LEGISLATION REGARDING FINANCIAL CRIME}

Prosecution of financial crime after 1944 took place in a situation where the legal system of the Second Polish Republic was partially undermined by the self-proclaimed authorities (Polish Committee of National Liberation, Provisional Government). What constituted a violation of the rules of economic life was decided by the provisions of various acts (including pre-war ones e.g. the Penal Code of 1932) but also in special legal acts adopted for the needs of emergency trials, including the military trials from 1944 on. Furthermore, there was a number of decrees and acts concerning the economic life which were either related to a very small part of the national economy or were of a temporary character, but which still included penal provisions [Wilk L. 2012: 36]. The summary of the main legal acts which discussed financial crime is included in the table below. 
Table 1. Legislation concerning economic crime, in force in the period 1944-1956

\begin{tabular}{|c|c|c|}
\hline Legal act & Section & Financial crime \\
\hline \multirow[t]{5}{*}{ Penal Code of 1932} & Chapter 27 & $\begin{array}{l}\text { Forging money, securities, official } \\
\text { marks and measuring apparatus - } \\
\text { articles 175-186 }\end{array}$ \\
\hline & Chapter 27 & Violation of secrecy - articles 253-254 \\
\hline & Chapter 39 & $\begin{array}{l}\text { Crimes against property - } \\
\text { articles } 257-272\end{array}$ \\
\hline & Chapter 40 & $\begin{array}{l}\text { Crimes against creditors - } \\
\text { articles 273-285 }\end{array}$ \\
\hline & Chapter 41 & Clerical offenses - articles 286-293 \\
\hline \multirow[t]{2}{*}{$\begin{array}{l}\text { Military Penal Code of September } \\
23,1944\end{array}$} & Chapter 24 & $\begin{array}{l}\text { Crimes against military property - } \\
\text { articles } 172-178\end{array}$ \\
\hline & Chapter 25 & $\begin{array}{l}\text { Field crimes against people and pro- } \\
\text { perty - articles } 180-186\end{array}$ \\
\hline \multirow{4}{*}{$\begin{array}{l}\text { Decree of November } 16,1945 \text { on } \\
\text { crimes posing a special threat in } \\
\text { the period of state reconstruction. } \\
\text { These were the tasks of the units } \\
\text { of the Security Service (article 38) }\end{array}$} & Chapter 1 & $\begin{array}{l}\text { Article } 2 \text { concerning acts of sabotage } \\
\text { Article } 4 \text { on forging and illegal ma- } \\
\text { nufacturing of money }\end{array}$ \\
\hline & Chapter 2 & $\begin{array}{l}\text { Article } 15 \text { on interrupting the intro- } \\
\text { duction of the agricultural reform } \\
\text { Article } 17 \text { on benefits in kind }\end{array}$ \\
\hline & Chapter 3 & $\begin{array}{l}\text { Crimes again the economic interest of } \\
\text { the state - articles } 25-29\end{array}$ \\
\hline & Chapter 4 & Clerical offenses - articles 30-31 \\
\hline $\begin{array}{l}\text { Decree of November 16, } 1945 \text { on } \\
\text { emergency proceedings }\end{array}$ & Article 1 & $\begin{array}{l}\text { Crimes stipulated in the Penal Code } \\
\text { of 1932: theft, robbery, armed robbery, } \\
\text { clerical offenses, clerical corruption }\end{array}$ \\
\hline \multirow{3}{*}{$\begin{array}{l}\text { Decree of June } 13,1946 \text { on crimes } \\
\text { posing a special threat in the pe- } \\
\text { riod of state reconstruction (with } \\
\text { amendments) - "small penal } \\
\text { code" }\end{array}$} & Chapter 1 & Article 3 concerning acts of sabotage \\
\hline & Chapter 2 & $\begin{array}{l}\text { Crimes against public order - article } 21 \\
\text { on benefits in kind }\end{array}$ \\
\hline & Chapter 3 & $\begin{array}{l}\text { Crimes again the economic interest of } \\
\text { the state - articles } 39-45\end{array}$ \\
\hline $\begin{array}{l}\text { Decree of May } 18,1949 \text { on the an- } \\
\text { nouncement of a consistent text } \\
\text { of the decree on emergency pro- } \\
\text { ceedings }\end{array}$ & Article 1. & $\begin{array}{l}\text { Item } d \text { concerning crimes to the harm } \\
\text { of the Treasury }\end{array}$ \\
\hline
\end{tabular}




\begin{tabular}{|l|c|c|}
\hline \multicolumn{1}{|c|}{ Legal act } & Section & Financial crime \\
\hline $\begin{array}{l}\text { Decree of October 26, 1949 on pro- } \\
\text { tecting state and service secrets }\end{array}$ & Chapter 1 & General provisions \\
\hline $\begin{array}{l}\text { Decree of August 5, 1949 on } \\
\text { protecting the freedom of } \\
\text { worship and conscience }\end{array}$ & Article 9. & On financial benefits \\
\hline $\begin{array}{l}\text { Decree of March 4, 1953 on } \\
\text { increasing collective property } \\
\text { protection }\end{array}$ & \multicolumn{2}{|c|}{ In total } \\
\hline $\begin{array}{l}\text { Decree of March 4, 1952 on } \\
\text { protecting collective property } \\
\text { against petty theft }\end{array}$ & \multicolumn{2}{|c|}{ In total } \\
\hline $\begin{array}{l}\text { Decree of December 23, 1954, } \\
\text { changing some provisions } \\
\text { concerning collective property } \\
\text { protection }\end{array}$ & \multicolumn{2}{|c|}{} \\
\hline
\end{tabular}

Source: own calculation.

\section{THE MINISTRY OF PUBLIC SECURITY}

One of the institutions that was responsible for enforcing the aforementioned provisions was the Ministry of Public Security. This institution, controlled entirely by the state, was also perfectly suited for supervising the economic transformations. This meant, for example, gradual organizational expansion and increasing employment in all positions. Officers of the Ministry could be found everywhere, from individual plants to ministries - every sector of economic life was, to a lesser or larger extent, subject to supervision.

At first, in 1944, Sections 4 and 6 of Department 1 were responsible for economic issues ${ }^{3}$. After the reorganization of the Ministry of Public Security in September 1945 [Paczkowski A. 1996] ${ }^{4}$, a separate Department no. 4 was created, which had branches and divisions in regions and counties. From the late 1940s, the organization of Prisoners' Work Camps (OPW) began. In 1949, special cells existing in the most important in-

\footnotetext{
${ }^{3}$ Division 4 (economic); Division 6 (communication).

4 The order of the Minister of Public Security of September 6, 1945.
} 
dustrial plants and managing institutions - Offices and Departments of Industry Protection and Military Offices - were brought under the authority of UB units. From December 1950 on, there was a separate Department 8 responsible for transport, which replaced the Rail Agency existing from the turn of the year 1946. In January 1953, Department 9, which dealt with heavy industry, was separated from Department 4. In June 1954, the Rural Inspectorate was created. Within the Ministry there were also units dealing with different aspects of economic activity, mainly related to the industry - the special unit (dealing with defense) and Departments " $\mathrm{H}$ " (foundry), “ $\mathrm{W}$ " (coal mining), “ $\mathrm{K}$ " (uranium mining) [Klementowski R. 2006: 79-126]. Thus, we can see not only the expansion of the security apparatus but even its specialization. The first reduction of the security structures occurred only with the dissolution of the Ministry of Public Security and the establishment of the Public Security Committee in December 1954. Economic issues then became the interest of two divisions: Division 4 (former Department 4 and Rural Inspectorate) and 5 (former Department 8) [AIPN (The Archive of the Institute of Public Remembrance) Wrocław, 053/409 vol. 1, ff 3-4].

The actions of the security institutions were correlated with the functioning of a number of state institutions on various levels of administration e.g. the courts for minor offences at national councils or the Special Commission for Fighting with Fraud and Economic Abuse created on November 16, 1945 [Journal of Laws, item 302: 476-477].

Formally, only selected crimes were under the jurisdiction of military courts, which meant that the security agencies were responsible for investigating the matter. In practice, in the period 1944-1956 every crime was a subject of interest of the secret police. Its officers prepared evidence for courts (including special and military courts - emergency courts, Military District Courts) and administration (courts for minor offenses at national councils). The involvement of the security services grew with the development of the systemic revolution. This fact was emphasized in the operational work documents.

The foundations of socialism are being built in the conditions of a fierce class fight in the cities and in the countryside. The bigger the successes and the achievements of the People's state, the fiercer the hostile reactionary elements (embarrassed and isolated), inspired and generously paid by the imperial intelligence, resort to vile and disguised methods of fight using espionage, diversion, sabotage, terror and hostile propaganda in various aspects of economic, political and social life in our country. The institutions of public security were established to fight with the enemies of the Polish People's 
Republic, to detect and eliminate all hostile elements, to paralyze the intentions of hostile imperialist centers [Ruzikowski T. 2004: 29]. ${ }^{5}$

As we see in the quote, diversion and sabotage in the economic life were named as the biggest threats, which meant that financial crime acquired political meaning. This is evidenced by the evaluations conducted by the ministry years later. In 1974, on the 30th anniversary of the creation of the Security Office and Citizens' Militia, an internal seminar was organized in the Regional Headquarters of Citizens' Militia in Wrocław concerning the engagement of the security units and Militia in protecting the national economy in Lower Silesia. Four papers were then presented whose subjects indicate indirectly that the most important issues from the point of view of the authorities in the 1940s and 1950s were: diversion, sabotage and financial crime (so the concepts were considered separate), protecting state and service secrets in industrial sites and, finally, conflicting situations in the national economy. The introductory paper discussed these issues in detail.

The role and the tasks of the Security Service and Citizens' Militia in this period (19451952) were particularly difficult and they entailed great responsibilities. Engaged in military fight against Wehrmacht and SS survivors, organized diversionary and espionage groups, Werewolf bands and various collaborators entering into cooperation with the domestic reactionary underground, they had to maintain public order and protect the recovery and reconstruction of the economy in Lower Silesia. Protection was provided for power plants, gas plants, industrial sites, means of communication, warehouses, food and equipment transports etc. (...) Economic reconstruction in Lower Silesia was at the same time accompanied by negative phenomena such as looting, thefts, secret illegal spirit production and drunkenness, speculation, black market, foreign currency trade etc. To prevent these problems, Citizens' Militia officers effectively fought with the so-called economic underground preying on the difficulties of the reconstruction period. Despite the economic difficulties and the obstacles created by the enemy and domestic reactionary circles, the economic achievements in Lower Silesia allowed the city of Wrocław to host, as early as in 1948, the Recovered Territories Exhibition, important for the country not only for economic, but also political reasons. (...) Our enemy, decisively defeated in the political aspect and in direct military fight, went deeper and deeper in the underground, moving on to more sophisticated methods of fight: sabotage, espionage and diversion [AIPN Wr, 054/512, f. 13].

The next years brought the need to solidify the economic transformations achieved so far.

${ }^{5}$ Order no. $025 / 53$ on the work of the public security bodies and their agency network. 
Everything that the nation built had to be protected against theft, robbery, appropriation and external penetration. In other words, the main task was protecting what had appeared owing to the sacrifice of the whole society of Lower Silesia (...) In the years 1952-1956, the Security Service protected important sites of the national economy against diversion and sabotage, eliminating still numerous illegal organizations and groups, which, for political reasons, resorted to hostile acts or planned them, with the intention to paralyze the economy, particularly in mining, power industry and transport. Espionage by foreign intelligence was also thwarted. In close cooperation with the Militia, scandalous actions and currency-related crimes were eradicated. The work of the units responsible for the fight against financial crime was concentrated primarily on the protection of consumers' interests and providing economic consistency between the urban and rural areas in terms of buying agricultural products and supplying the countryside with equipment. The officers of these units put a lot of effort into investigating and eliminating criminal groups that infiltrated the purchasing centers and other branches of the Lower Silesian economy [AIPN Wrocław, 054/512, ff 13-14].

Based on the operational and administrative documentation and reports one can identify a set of problems present in Poland after the war which were treated by the security service as financial crime.

In a national briefing in the Ministry of Public Security in 1951, it was pointed out that:

[...] as the working class took over power in Poland after 1944, the process of transforming the Polish nation began, from a bourgeois nation into a socialist nation with a new economic structure, new class composition and a new moral and political face. The first steps were the historic decrees on agricultural reform and industry nationalization through which capitalists and landowners were expropriated, which removed the basic pillars of the former bourgeois society from our life forever. In the six years of People's rule, the working class in cooperation with the rural poor and middle-sized farmers have been transforming the face of the nation under the management of our Party in a fierce class struggle [AIPN, Wrocław, 053/422, f. 123].

The management of the security agencies paid a lot of attention to the ideological training of the officers in the economic divisions. From the very beginning of PUWP, the engagement of the security in economic affairs was justified by the alleged activity of the "enemies of the system" who allegedly acted against the achievements of the authorities during the period of the economic reconstruction. This was in line with the dominant narrative of a "fiercer class struggle". As it was explained:

[...] in basic aspects of the economic life there are more and more acts of diversion, there is more mouth-to-mouth hostile propaganda and other forms of hostile and criminal activity". The guilty were found in the circles earlier defined as hostile: from the coope rators of foreign intelligence to the people associated with the opposition, conspiracy 
Table 2. The forms of hostile actions in the economy according to the assessment of the security agencies in the early 1950s.

\begin{tabular}{|c|c|}
\hline $\begin{array}{l}\text { Sector } \\
\text { of the economy }\end{array}$ & Examples of "hostile" actions \\
\hline Industry & $\begin{array}{l}\text { - "acts of diversion": setting fires to plants and industrial equipment; } \\
\text { blowing up foundry furnaces; destroying equipment; pouring sand } \\
\text { or pieces of iron into gearboxes, bearings and electric motors; immo- } \\
\text { bilizing machines and whole technical units; destroying ready prod- } \\
\text { ucts etc.; } \\
\text { - sabotage: noncompliance with applicable provisions and regula- } \\
\text { tions at work and enabling the emergence of thousands of so-called } \\
\text { technical failures; creating the possibilities for the existence of waste- } \\
\text { fulness; hampering the implementation of state plans in terms or } \\
\text { production, investment, supply and sale; } \\
\text { - deliberate hampering of work organization improvements and of } \\
\text { technological process rationalization; } \\
\text { - deliberate hampering of competition at work, maintaining bad } \\
\text { quality, limiting product ranges and constantly increasing costs; } \\
\text { - accepting failures by the administration and technical staff and } \\
\text { justifying them with objective reasons such as machine wear, lack } \\
\text { of spare parts or geological conditions; deliberate disorganization of } \\
\text { the reconstruction and construction plans; neglecting preparatory } \\
\text { works (in coal mining industry); lack of competence among staff; } \\
\text { - unjustified overestimation of production figures, misrepresenting } \\
\text { the governmental guidelines concerning distribution; } \\
\text { - organizing strikes and fostering strike moods; employing the hos- } \\
\text { tile element "under the influence of WRN (the Freedom, Equality, } \\
\text { Independence Party)"; } \\
\text { - the activity of hostile intelligence, particularly in statistical and re- } \\
\text { porting units, deliberately keeping information non-secret and re- } \\
\text { vealing data on the industry. }\end{array}$ \\
\hline Internal trade & $\begin{array}{l}\text { - diversion: setting fires to warehouses and stocks, destroying prod- } \\
\text { ucts meant for distribution; } \\
\text { - sabotage: causing imbalances in the market through incorrect dis- } \\
\text { tribution policies, freezing working capital; } \\
\text { - harmful activity involving enabling capitalist elements to infiltrate } \\
\text { cooperative and state structures; creating companies that acted as } \\
\text { cooperative, but were actually capitalist etc.; } \\
\text { - sabotaging governmental guidelines in terms of product distribu- } \\
\text { tion (WRN groups). }\end{array}$ \\
\hline Foreign trade & $\begin{array}{l}\text { - connection of many elements of foreign trade with foreign capital- } \\
\text { ist companies, espionage for foreign intelligence; } \\
\text { - which resulted in suspending deliveries of vital equipment, im- } \\
\text { posing difficult conditions and imposing some products by partners } \\
\text { from the West; }\end{array}$ \\
\hline
\end{tabular}




\begin{tabular}{|c|c|}
\hline $\begin{array}{l}\text { Sector } \\
\text { of the economy }\end{array}$ & Examples of "hostile" actions \\
\hline $\begin{array}{l}\text { Treasury } \\
\text { and banking }\end{array}$ & $\begin{array}{l}\text { - espionage, involving gathering data on all aspects of the economic } \\
\text { life and communicating them to foreign intelligence centers; } \\
\text { - employing hostile element, which protected the interests of the } \\
\text { capitalist sector in many units of the treasury and banking sectors. }\end{array}$ \\
\hline $\begin{array}{l}\text { Agriculture - } \\
\text { national }\end{array}$ & $\begin{array}{l}\text { - taking control over the important elements of administration by } \\
\text { "hostile groups related to Mikołajczyk, former landowners, exposed } \\
\text { members of Freedom and Independence, National Armed Forces, SB } \\
\text { OUN organizations, former employees of the Delegation, etc." en- } \\
\text { gaged in sabotage activities; } \\
\text { - acts of diversion: setting fires to facilities, equipment, crops etc., de- } \\
\text { stroying tractors (deliberate faulty reconstruction by the Agriculture } \\
\text { Maintenance Service) and other technical equipment, killing cattle } \\
\text { and swine; } \\
\text { - underestimating the seeding plans, seeding crops in bad soil, de- } \\
\text { liberate delays in seeding, lack of supply of seeds, deliberate disor- } \\
\text { ganization of fertilizing actions and falsifying instructions for using } \\
\text { fertilizers etc.; } \\
\text { - fiercer class struggle in the countryside manifests in the increased } \\
\text { number of mugging incidents, murders and robberies, setting fires } \\
\text { and the waves of "enemy-inspired propaganda" } \\
\text { - in countryside reconstruction: incidents of granting reconstruc- } \\
\text { tion loans to private land owners and priests and denying loans to } \\
\text { farmers with little land; conducting poor quality work resulting in } \\
\text { quick degeneration of buildings, overpricing construction of farm- } \\
\text { ers' houses by private businessmen or county architects related to } \\
\text { them. }\end{array}$ \\
\hline Other & $\begin{array}{l}\text { - acts of diversion in the Polish Rail: blowing up trains, organizing } \\
\text { rail disasters, setting fire to carriages, acts of diversion towards tran- } \\
\text { sit Soviet trains; } \\
\text { - deliberate delays in repairs, performing work badly on purpose, } \\
\text { not using the fleet of repair garages; } \\
\text { - hostile element from the Freedom and Independence organization } \\
\text { and others as the center of espionage activities; } \\
\text { - incidents of corrupting the economic institutions of the state on } \\
\text { a massive scale, infiltrating some elements of the economic struc- } \\
\text { tures by the capitalist sector in order to commit criminal and hostile } \\
\text { activities, abuses on mass scale. }\end{array}$ \\
\hline
\end{tabular}

Source: Author's own development based on the reports of Department 4 of the Regional Office for Public Security and Division 4 of the County Office for Public Security in Lower Silesia. 
or even an "armed underground". What is more important, their activity was linked to the former capitalist circles which "infiltrated" the collective economy, very often occupying managerial positions [AIPN Wrocław, 01337/7, f. 1].

Financial crime was looked for on the junction of state and private business, with the latter allegedly "sponging" off the collective property. For example, in 1949, a part of management of the National Railway Carriage Factory in Wrocław was detained and accused of accepting bribes from private companies providing materials (wood, paint) of a worse quality than stated on the invoices. The alleged loss was 100 million PLN [AIPN Wrocław, 247/7 vol. 1, ff 24-25]. Using managerial positions for private purposes was one of the recurring themes in the Security Office materials: thefts, using company cars, occupying flats etc. Interventions of security officers were met with approval on the side of workers who, for the most part, were in a bad financial situation [AIPN Wrocław, 032/182].

Motivations of people committing those crimes were regularly described as political,
and this was also the message sent to the officers. It is obvious that there are still class
differences here, that the class enemy (seeing its inevitable demise) defends itself even
more fiercely, that various reactionary elements resort to even more brutal methods
of fight... The Polish nation, transforming into a socialist nation, united in the national
front, is implementing its 6-year plan for Poland's reconstruction and national wellbe-
ing with heroic effort - while the class enemy is opposing that, sabotaging the efforts
and acting to our harm; the nation united in the national front is increasing the fight
with the American war instigators who are preparing an attack on Poland, who con-
stitute a threat to the independence of our homeland and bring death and destruction
to the nation - while the class enemy, loyal as a dog, serves these criminals and spies
and promotes a new war [AIPN Wrocław, 53/422, ff 127,130$]$.

Furthermore, it was pointed that less attention is paid to financial crime than to murders or armed robberies [AIPN Wrocław, 53/422, f. 227]. In one sitting of the management of the Ministry of Public Security, Minister Radkiewicz announced that the first half of the 1950s would be concentrated on fighting with problems referred to as "sabotage", "diversion", "economic abuse" by the service.

The problem of fighting with hostile, criminal acts on the economic front is on top of the list of all tasks for all the forces and all departments of the public security agencies, and it must be known that tasks on this front will keep growing over the next years [AIPN Wrocław, 53/422, f. 226]. 


\section{EFFECTIVENESS OF FIGHTING FINANCIAL CRIME}

Establishing the results of the actions of the security agencies dealing with the industry, agriculture or trade remains the most difficult problem. Even the number of arrests for financial crimes seems uncertain. Firstly, this category only emerged in statistics after several years. Secondly, in many cases, particularly in the field, people would often be arrested without any evidence and soon let go. Ironically, they were included in the statistics, but for a long time, without a separate category. The situation in Lower Silesia in 1946 has to be considered exceptional - 5 people were arrested for "sabotage" back then [AIPN Wrocław, 274/22, f. 21]. The available figures are from later years.

The accused could face heavy punishment, and the repressive nature of the system only increased in the period. For example, in 1949 in Lower Silesia, 8 out of 300 people detained for financial crime were sentenced to death, one was sentenced to life imprisonment and seven to between 10 and 15 years in prison. One of the most controversial cases was that of Czesław Plichta, a scrap collector, who was sentenced to death and executed for "vandalizing" railway engines left in one of the sidetracks in Wrocław. Plichta's collaborator was sentenced to 15 years in prison [AIPN Wrocław, 247/ 7 vol. 2, f. 20]. This was a typical show trial supposed to defer other possible "fans" of collective property.

Graph 1. The number of arrests for financial crimes in the years 1945-1956 in the Wrocław region

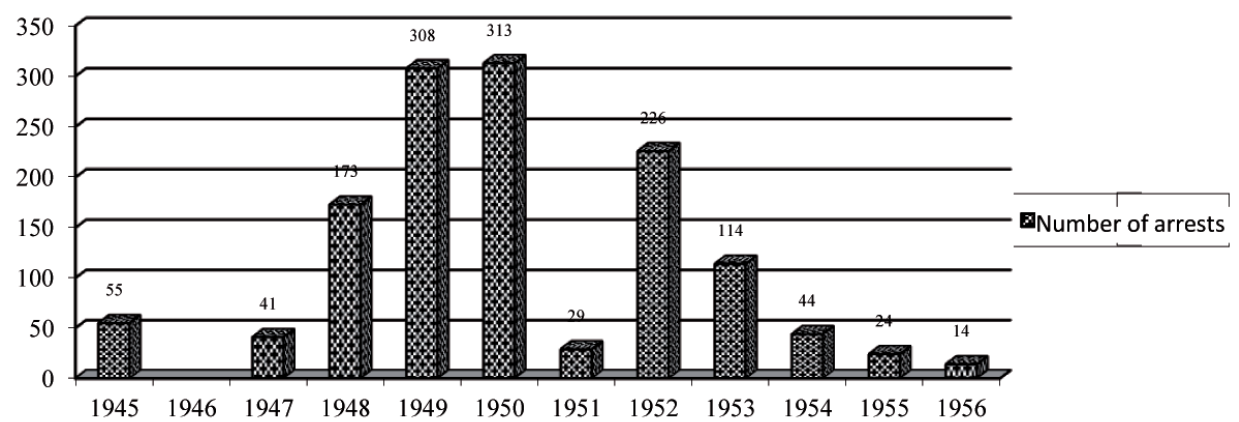

Source. AIPN Wrocław, sign. 0297/16, Organization and structure of the public security agencies and the manifestations of hostile actions of the reactionary underground and preventive actions of the agencies in the years 1945-1969 in the Wrocław region. 
The expanded structure of the security generated numerous reports of a statistical and descriptive character [AIPN Wrocław, 053/400, f. 45]. Their scope changed over time, depending on needs or interests of the authorities [AIPN Wrocław, 053/402, f. 28]. The more important economic issues were, the more detailed the reports. Examples include distinguishing in 1949 financial crimes in industry and in agriculture within the category of sabotage, and separating attacks on cooperatives from political banditry [AIPN Wrocław, 053/403 vol. 1, ff 161-162].

The materials were primarily used by the security for their own purposes, that is, in operational activities. Once processed, they were sent further, to the communist party, administration, industrial plants and propaganda offices. Anyone researching the documentation created by the security faces an important problem of the credibility of these materials. It is justified due to a number of problems accompanying the work of the economic departments of the Security Office. Firstly, these structures suffered from constant staff shortages, therefore the possibilities of supervising the society were limited. Secondly, the work of the service were to a large extent organized as "actions", in response to the current political needs. Thirdly, and probably most importantly in the long run, throughout the whole period described, the service struggled with a lack of substantial knowledge among officers. In many cases these officers could not properly evaluate the problems they dealt with. Bribery did not pose a serious problem to them, but when it came to explaining the causes of failures or interferences with the production process in industry, it was beyond the scope of understanding for an average employee of the department. The management often emphasized that the role of the Security Office in the process of purging the economy was not understood.

Members of these circles arrested in relation to the incidents of failures are in many cases not investigated in depth by the officers. Very often we cannot investigate the cases of economic abuse from the political point of view. We cannot find a causal relationship between the failure or some other type of damage and the political past of the suspects [AIPN Wrocław, 053/407 vol. 1, f. 266].

The consequence of these problems was the inevitable, and to some extent even not deliberate, falsification of statistics. Often, it was impossible to put the incident into the right category (coincidence - failure - accident - sabotage/diversion?). The need to please one's superiors resulted in operational hyperactivity. 
In the work of Department 4, there still remains a tendency to call every type of crime in the economy a "sabotage". That is how data on hundreds of sabotage cases and of great "results" of our field teams' work are gathered. Out departments keep those "successes" to themselves, they do not want to share them with other forces, they burden themselves with massive investigative work in many abuse-related cases, and since the main task is the fight with sabotage then these cases are referred to as sabotage-related. With this mass "production" of data, the real sabotage cases are lost, we do not work with agents, we do not look for agents and even the promising cases elude us because of the superficial investigations [AIPN Wrocław, 053/407 vol. 1, f. 15].

The most important tool that the security services had, i.e. informants, also failed, and at the end of the period described, the poor detection rate of accidents in the industry was believed to be due to the small number of agents and the primitive operational inquiries.

Internal assessments of the repressive policy indicate an interesting problem - as it turns out, the circles that should be interested in solidifying the transformations taking place dominated among the arrested. From the analysis for the year 1952 we learn that:

[...] kulaks, degraded capitalist elements, landowners and reactionary priests altogether comprise less than $2.5 \%$ of the total number of the arrested for this crime. $42 \%$ of the arrested are workers, $38 \%$ are peasants and $17.5 \%$ are working intelligentsia. If one takes into consideration that from the total number of the arrested for hostile propaganda, the majority are people unrelated to any hostile organizations or political groups, then it becomes clear that our penal policy when it comes to fighting with hostile propaganda is fundamentally misguided and contrary to the directives of the Party and the management of the Public Security [AIPN Wrocław, 053/407 vol. 1, f. 278].

The so-called hostile propaganda is mentioned here, but similar figures are given in the context of financial crime.

\section{THE BREAKTHROUGH OF 1956 - AN ATTEMPT TO FIND A NEW PERSPECTIVE}

After 1956, the first attempts were made at explaining what financial crimes were in the first decade of the Polish People's Republic. Taking into consideration the practices of the security agencies up to this point, there was a proposal to divide the crimes into four categories, combining the objective, subjective, and personal criteria. The objective criterion result- 
ed from the fact that the constitution of 1952 included the term "totality of the state's economic relations", which contained a static element (collective property) and a dynamic element (economic life based on collective property). This was the basis for defining crimes aimed against the normal course of the economic life [emphasis by the author]. These were e.g.:

[...] a group of situations related mainly to production and trade, e.g. illegal production and trade, violation of the standard, quality and pricing provisions, privileging buyers, unfair competition, using forged measuring apparatus, forging money and securities, false accountancy, illegal trade and speculation, currency and customs related crimes etc. [Cyprian T. 1958: 24].

The second category defined based on this criterion were crimes against collective property [emphasis by the author] - e.g. causing damages or appropriation. As a part of the second - subjective - criterion, the existence of counter-revolutionary crimes [emphasis by the author] was pointed out. Their aim was not gaining personal benefits but "disrupting the normal course of the economic life", sabotage and diversion. The personal criterion included the professional offenses [emphasis by the author] on the economic front - i.e. appropriating professional goods, revealing trade secrets, mismanagement, and crimes against economic planning and control. The term "mismanagement" denoted "gross negligence of one's responsibilities, beyond disregard or carelessness" [Cyprian T. 1958: 17-29].

\section{CONCLUSION}

Financial crime resulting from shortages on the market led to the development of adaptive mechanisms in the society, in the form of the following behaviors: common theft, "fixing", evading law, disrespectful attitude towards collective property and, most importantly, silent permission for the existence of these phenomena understood as "resourcefulness". Artur Śliwiński explained the problem in relation to the German occupation:

The so-called nationalization was a radical and all-encompassing destruction of the system of public security: on the one hand by resorting to common terror, and on the other by making society poorer, which resulted in less protection from the occupational authorities (...) The ability to exercise control and take risks diminishes along with the diminishing capital assets. In this context, depriving people of property is an effective method of limiting their ability to exercise control and take risks. Society, faced 
with risk, becomes vulnerable or resorts to methods of survival based on avoiding risk by all means [Śliwiński A. 2004: 127].

The attempts of including and defining financial crimes in legal penal acts made after 1944 resulted from temporary need and were not of a fundamental character [Cyprian T. 1958: 33]. These provisions met specific needs of the economic life in a vague manner. The situation was similar with the "March decrees" (of March 4, 1953). This resulted from the fact that the law operated in a situation of co-existence of three economic sectors, whereas the notions of "collective property", "economic planning" and "socialist economy" were only being introduced.

From the point of view of legal practice, many provisions were unclear, for example, in the "small penal code", sabotage included not only destruction of public facilities, transportation and defense equipment, but also delivering faulty (and thus useless) items to the army. The latter case was dubious, though, as the actions of the perpetrator could result not from any counter-revolutionary intentions by from the will to profit illegally [Cyprian T. 1958: 34]. Furthermore, in the period described, some provisions were in force only temporarily, for example those on preventing or interfering with the implementation of agricultural reform, looting, removing property from the Recovered Territories or removing property by the displaced [Cyprian T. 1958: 35]. In the late 1940s, these provisions became dead, as the problems they concerned ceased to exist.

The severity of punishments, emphasized in literature [Szwagrzyk K. 2005], was explained by the needs of the times of reconstruction, however at the same time, the general character of certain concepts allowed for free interpretation of the actions committed by the suspect. For example, section 2 (2) of the Decree on crimes posing particular danger in the period of state reconstruction, defined a saboteur as anyone who made it difficult or impossible for industrial plants or equipment to operate correctly. The decision whether a given behavior fulfills the criteria of "making impossible" or "difficult" was freely made by law enforcement agencies (when initiating investigations and collecting evidence), prosecutor (arrest, indictment), and finally courts (verdict). This was a convenient tool for the authorities who could act either firmly or mercifully. For the individual, the price of the latter was usually becoming dependent, at the disposal of the special services who used blackmail to enforce cooperation, or in other words - denouncing others. And, as evidenced by the archive materials of the security agencies, they often seized this opportunity. 
This repressive nature of the law in the first decade of the Polish People's Republic was officially criticized by lawyers after 1956.

First of all, we must get rid of the illusion that all economic difficulties, every disruption of balance between supply and demand, every failure resulting from the lack of competent staff, can be purged with legal sanctions [Cyprian T. 1958: 37].

Concluding this argument, the author wrote that the long crisis means that "even risk combined with the threat of severe punishment starts to pay off..." [Cyprian T. 1958: 37].

Janusz Zajdel, a Polish physicist and writer described in his books (which have remained popular to this day) the functioning of a total government system with a state-controlled economy. ${ }^{6}$ Life in this world would be unbearable if it was not for the black market, protecting the needs of people which the system could not satisfy. The authorities were also aware of that, turning a blind eye to a number of acts bordering on illegal - or outright criminal. Owing to that, social activity was channeled towards improving one's own existence, "fixing" and "arranging" things. At the same time, this meant that a great majority of people was guilty of bigger or smaller offenses and, if necessary, they could be disciplined with a threat of heavy punishments. This vision, although fictional, without a doubt has much in common with the reality in Poland under the Polish United Workers' Party rule, and reflects the reasons behind the interest in financial crime among the special services, which served as a supervising, reporting, operating, investigating and repressing body.

\section{BIBLIOGRAPHY:}

ARCHIVE MATERIALS

Archiwum Instytutu Pamięci Narodowej Wrocław (The Archive of the Institute of National Remembrance in Wrocław - AIPN Wrocław)

AIPN Wrocław, sign. 053/409, Vol. 1, Decisions, orders and reports of the WUBP (Regional Office for Public Security) for the period from January to June 1955, report of the manager of WUdSBP in Wrocław, Wrocław, 3 I 1955, ff 3-4.

AIPN Wrocław, sign. 054/512, Specialist seminar on the subject: "The role of the Security Service and Citizens' Militia in protecting the interests of the national economy in Lower Silesia in the last 30 years", Wrocław 1974, ff 13-14.

${ }^{6}$ The book "Limes inferior" published in 1982 is particularly worth recommending. 
AIPN Wrocław, sign. 053/422, Materials from national briefings for the years 1949, 1951 and 1952, f. 123.

AIPN Wrocław, sign. 01337/7, The guidelines of Department 3 of the Ministry of Public Security for 1949-1954, f. 1.

AIPN Wrocław, sign. 247/7, Vol. 1, Report on the work of the investigative department of WUBP in Wrocław for February 1949, Wrocław, March 7 1949, ff 24-25.

AIPN Wrocław, sign. 032/182, Operational file for Sułkowice sugar factory and Silesia Chemical Plant in Jawor

AIPN Wrocław, sign. 053/422, Materials from national briefings for the years 1949, 1951 and 1952, ff 127,130.

Ibidem, Materials from the national briefing on September23, 1952, final speech of minister Radkiewicz, f. 227.

Ibidem, f. 226.

AIPN Wrocław, sign. 274/22, A 10-year report of WUBP Wrocław to the Ministry of Public Security in Warsaw, Warsaw, June 25, 1946, f. 21.

AIPN Wrocław, sign. 247/7, vol. 2, Report on the work of the Investigative Department of WUBP in Wrocław for the period from August 1, 1949 until September 1, 1949, Wrocław, September 8, 1949, f. 20.

AIPN Wrocław, sign. 053/400, Regulations, instructions and orders of the head of WUBP in Wrocław for the year 1946, vol. 1, A letter of the manager of WUBP in Wrocław to the manager of PUBP in Ząbkowice, Wrocław, January 25, 1946, f. 45.

AIPN Wrocław, sign. 053/402, Regulations, orders, instructions, bulletins of WUBP Wrocław for the period of January-June 1948, Attachment no.4 to bulletin no. 2 of the head of WUBP in Wrocław, Wrocław, January 21, 1948, f. 28.

AIPN Wrocław, sign. 053/403, vol. 1, Regulations, orders and bulletins of WUBP Wrocław for the period January-June 1949, A letter of the head of the investigative department of WUBP in Wroclaw to the head of PUBP in Trzebnica, Wrocław, May 27, 1949, ff 161-162.

AIPN Wrocław, sign. 053/407, vol. 1, Regulations, instructions, orders and letters of WUBP for the period January-June 1953, The tasks of the investigative services in the fight to strengthen the rule of law and strengthen the People's State, no date, f. 266.

Ibidem, f. 15.

AIPN Wrocław, sign. 053/407, vol. 1, Regulations, instructions, orders and letters of WUBP for the period January-June 1953, The tasks of the investigative services in the fight to strengthen the rule of law and strengthen the People's State, no date, f. 278.

\section{LITERATURE}

Cyprian T. (1958), Dotychczasowa kodyfikacja przestępstw gospodarczych [The existing codification of financial crimes], "Nowe Prawo" no. 21.

Cyprian T. (1958a) , Próba określenia przestępstwa gospodarczego [An attempt to define financial crime], "Ruch Prawniczy, Ekonomiczny i Socjologiczny" no. 3.

Journal of Laws, no. 53, item 302 of November 16, 1945.

Klementowski R. (2006), Wydziat IX Departamentu IV MBP/Wydział IX "K” WUBP we Wroctawiu z siedziba w Kowarach (struktura, działalność, obsada personalna) [Section 9 of Department 4 of the Ministry of Public Security/ Section 9 "K" of WUBP in Wrocław, seated in Kowary (organization, activities, staffing)], "Aparat represji w Polsce Ludowej 1944-1989”, Rzeszów no. 4.

Lernell L. (1959), Uwagi o pojęciu przestępczości gospodarczej [Remarks on the notion of financial crime], "Państwo i Prawo" no. 11. 
Madej K. (2010), Bezradność lub represja. Wtadze wobec przestępczości gospodarczej w PRL (1956-1970) [Helplessness or repression. The authorities and financial crime in socialist Poland (1956-1970)], Warsaw.

Paczkowski A. [ed.] (1996), Aparat bezpieczeństwa w latach 1944-1956. Taktyka, strategia, metody. Część I. Lata 1945-1947 [Security services in the years 1945-1947. Tactics, strategy and methods. Part 1. Years 1945-1947], Warsaw.

Śliwiński A. (2004), Życie wśród tupieżców. Historia kryzysów i upadku gospodarczego Polski [Life among looters. The history of crises and the economic demise in Poland], Warsaw.

Szwagrzyk K. (2005), Prawnicy czasu bezprawia. Sędziowie i prokuratorzy wojskowi w Polsce 1944-1956 [Lawyers in times of lawlessness. Judges and military prosecutors in Poland 1944-1956], Kraków-Wrocław.

Ruzikowski T. [ed.] (2004), Instrukcje pracy operacyjnej aparatu bezpieczeństwa 1945-1989 [The instructions for operational work of the security services 1945-1989], Warsaw.

Wilk L. (2012), Przestępczość gospodarcza - pojęcie, przyczyny, sprawcy [Financial crime - concept, causes and perpetrators], "Edukacja Prawnicza" no. 10.

Robert Klementowski - Ph.D is a professor at the University of Wrocław, historian, anthropologist, scholar of literature. He researches communist secret police, the history of utopias, and anthropology of remembrance. He is the author of numerous publications including the following studies: Modelowe boksowanie ze światem. Polska literatura fantastyczna na przetomie lat 70 i 80 [Representative boxing with the world. Polish fantasy literature at the turn of the 1980s] (Torun 2003); Urzad Bezpieczeństwa w powiecie Lwówek Śląsi (1945-1956) [The Security Office in Lwówek Śląski county (1945-1956)] (Wrocław 2006); W cieniu sudeckiego uranu. Kopalnictwo uranu w Polsce w latach 1948-1973 [In the shadow of the Sudety uranium. Uranium mining in Poland in the years 1948-1973] (Wrocław 2010); Jeleniogórskie orlęta [Jelenia Góra eaglets] (Jelenia Góra 2011). 